\title{
Technology at the Service of the Elderly
}

\section{La tecnología al servicio de los adultos mayores}

A tecnologia ao serviço das pessoas idosas

Vitor Manuel Costa Pereira Rodrigues'

KEYWORDS (SOURCE: DeCS)

Technology; the elderly; delivery of health care; family; robotics.

PALABRAS CLAVE (FueNTE: DeCS)

Tecnología; anciano; prestación de atención de salud; familia; robótica.

PALAVRAS-CHAVE (Fonte: DeCS)

Tecnologia; idoso; assistência à saúde; família; robótica.

DOI: 10.5294/aqui.2020.20.1.1

Para citar este editorial / To reference this editorial / Para citar este editorial

Rodrigues, VMCP. Technology at the Service of the Elderly. Aquichan. 2020;20(1):e201l. DOI: https://doi.org/10.5294/aqui.2020.20.1.1

1 https://orcid.org/0000-0002-2795-685X. Research Center in Sports Sciences, Health Sciences and Human Development (CIDESD); School of Health, University of Trás-os-Montes e Alto Douro, Portugal.vmcpr@utad.pt 
As we all know, aging is a natural process and entails many changes and limitations for people. In this regard, it should be recalled that in 2015 the United Nations approved the 2030 Agenda for Sustainable Development whose third objective states that it is necessary to guarantee a healthy life and promote well-being for all at all ages (1).

When aging is associated with limitations, they are related to multiple health problems and the consequent search for better healthcare and medical attention by the family/informal caregivers, especially because of care needs and the concern for the elderly's well-being and quality of life, increases steadily, either if they are at home or in nursing homes. Of course, this concerns the elderly, but also their family members (2), and there has been a need for developing new technological systems that enable families and even health professionals to accompany their elderly (3).

With this concern, some researchers at University of Trás-0s-Montes e Alto Douro (Portugal) are carrying out two projects in the area of technologies and old people (4), namely, "NIE - Natural Interfaces with the Elderly" whose main objective is to develop new forms of relationship between the elderly and family/friends in order to reduce loneliness and contribute to a better quality of life, and "IPAVPSI - Impact of a therapeutic plan assistance and surveillance program supported by a sensor network on promoting the health of the dependent elderly at home" whose main objective is to implement several sensors (mobilization, body temperature, humidity, and medication) that help the informal caregiver to fulfill the therapeutic plan.

When we mention new forms of relationship, we are talking about telepresence robots that are similar to videoconferencing equipment; however, they have a feature for the user (family/ friends/healthcare professional) to make a call and remotely control the physical displacement of the equipment by taking the robot to where their relative is. At the technical level, the robotic telepresence equipment is usually composed of a screen, a camera, microphones, speakers, and a locomotion system, allowing communication between the two parties.

In a pilot study conducted in a nursing home in northern Portugal, and with a view to promoting social interaction, decreasing Ioneliness, and increasing the elderly's quality of life and well-being, calls through the telepresence robot were tested with ten seniors.
It was found that the average call duration using the robot was 7.60 minutes, and at the end of the call with the telepresence robot, $70 \%$ of the elderly expressed joy. Relatives of these ten seniors who interacted with them through the telepresence robot rated the experience with the robot as "very interesting." It should also be noted that the workers in this nursing home considered this experience very useful and described it as a "different way of interacting," "a necessary good," "a novelty." They also highlighted the ease with which the "elderly can interact with relatives," and stated that the elderly would like to continue interacting with their relatives through the robot.

Regarding the aid and surveillance programs for therapeutic plans supported by a sensor network in promoting the health of the dependent elderly at home, we must be aware that the aging index leads to more chronic diseases and greater dependence by the elderly. Many old people have difficulty moving and are often bedridden. Immobility produces pathophysiological and musculoskeletal alterations that cause deformities and postural affections, which increases the appearance of pressure injuries (5). If there is no regular care, these changes will affect the quality of life of the elderly, predisposing them to the onset of diseases (6). It should be emphasized that care for the dependent elderly at home is mostly provided by the family and/or informal caregivers. And the caregiver, when assuming the responsibility for this care, faces many difficulties regarding adherence to the therapeutic plans established by the health team (7).

At present, we are beginning the informal caregiver's difficulty assessment phase and to test respiration, heart rate, humidity, body temperature, position change, and fall detection sensors with a view to implementing care and surveillance plans of the therapy instituted. At the same time, a web interface will be built where family, informal caregivers, and health professionals can see in real time what is happening to their family member.

Reflecting on the theme of this article "Technology at the Service of the Elderly," we note that:

i) The ability to communicate by video call and the mobility that is provided by robot control creates a sense of presence on both sides and enhances the well-being of the elderly and family members by cutting the physical distances - normally existing in this context- and fostering social interaction. 
These systems help the elderly to overcome the feeling of social isolation and loneliness that affects their physical, mental, and emotional health (3).

ii) Caring for an elderly person requires that the family/informal caregiver restructure their lives because caregiving also means following the therapeutic plans established by the health team (8). And here, clearly, we can point out the benefits of installing a sensor network, especially because alerts/ alarms can take the form of sounds or written messages for family, informal caregivers, and healthcare professionals, as well as the web interface that allows a real-time 24-hour monitoring of everything that happens to the elderly.

iii) Telepresence robots, as well as therapeutic plan support and surveillance programs using a sensor network, do not replace or intend to replace the human factor — whether social, family, or health support-, but complement the care for the elderly, which is increasingly relevant to the work that health professionals performs.

\section{References}

1. United Nations. Transforming our world: the 2030 agenda for sustainable development, A/res/70/1. United Nations; 2015. Available from: https://www.un.org/sustainabledevelopment/sustainable-development-goals/

2. Warpenius E, Alasaarela E, Sorvoja H, Kinnunen, M. A mobile user-interface for elderly care from the perspective of relatives. Informatics for Health and Social Care. 2015;40(2):113-124. DOI: https://doi.org/10.3109/17538157.2013. 879148

3. Koceski S, Koceska N. Evaluation of an assistive telepresence robot for elderly healthcare. Journal of Medical Systems. 2016;40(5):1-7. DOI: https://doi.org/10.1007/s10916-016-0481-x

4. School of Health and School of Science and Technology. Project SAICT-POL/24048/2016 - "NIE - Natural Interfaces with the Elderly" and project SAICT-POL/ 23428/2016 - "IPAVPSI - Impact of a therapeutic plan assistance and surveillance program supported by a sensor network. [Portugal]: University of Trás-os-Montes and Alto Douro; 2018.

5. Silva J, Santos C, Zoche D, Argenta C, Ascari R. Diagnósticos e cuidados de enfermagem para pacientes com risco de lesão por pressão: relato de experiência. Brazilian Journal of Surgery \& Clinical Research. 2017;20(1):98-103. Available from: https://www.mastereditora.com.br/periodico/20170905_173650.pdf

6. Assis V, Vidal A, Dias F. Avaliação postural e de deformidades em idosos acamados de uma instituição de longa permanência. Revista Brasileira de Ciências Do Envelhecimento Humano. 2015;12(2):123-133. DOI: https://doi.org/10.5335/rbceh.v12i2.4926

7. Nunes D, Brito T, Corona L, Alexandre T, Duarte Y. Idoso e demanda de cuidador: proposta de classificação da necessidade de cuidado. Revista Brasileira de Enfermagem. 2018;71(suppl2):897-904. DOI: http://doi.org/10.1590/00347167-2017-0123

8. Monteiro MJ, Barroso I, Rodrigues V, Soares S, Barroso J, Reis A. Designing and Evaluating Technology for the Dependent Elderly in Their Homes. In: Antona M, Stephanidis C, editors. Part of the Lecture Notes in Computer Science book series (LNCS, volume 11573). 2019. pp. 506-510. DOI: https://doi.org/10.1007/978-3-030-23563-5_40 